\title{
Technological Capacity in Public Sector: The Case of Estonia
}

Lember, V.; Kattel, R. and Tõnurist, $P$.

\section{Abstract}

Technology is clearly a critical factor in lives of organizations, yet there are only few studies that deal with technology and public organizations. In this paper we propose to understand technological change in public sector, in particular how technology influences administrative capacity, through a new concept of technological capacity. We use the case of Estonia - internationally associated with a strong e-state profile - as an exploratory case to answer two research questions: why and how technological change takes place in public sector, and how does technological change influence administrative capacity in public organizations. We demonstrate how dynamic and static change in technological capacities is influenced by four different public sector feedback and selection mechanisms. We conclude that in spite of neglected position of technology in public administration literature, technology is an intrinsic factor in how administrative capacity evolves.

\section{Points for practitioners}

This article argues that technological change in public sector is not just a matter of technical skills, but technology changes fundamentally how public organizations function and how services are delivered. There are, however, key differences in speed and direction of how technology's impacts unfolds in various organizations and services. Some organizations master to develop dynamic technological capacities and experience rapid and transformative changes, and others do not and accordingly go through incremental changes. This difference has both internal and external causes. Those organizations to show dynamic technological capabilities manage well ambidexterity: to seek new solutions while managing to offer high level services. We provide new explanations why this is the case.

Keywords: technological capacity; public sector innovation; digital government; Estonia 


\section{Acknowledgments}

This project has received funding from the European Union's Horizon 2020 research and innovation programme under the Marie Skłodowska-Curie [grant number 750378] and the Estonian Ministry of Education and Research [grant number IUT 19-13]. The views expressed in this article are solely those of the author in a private capacity and do not in any way represent the positions of OECD or any other organisation or institution.

\section{Biographical notes}

Veiko Lember, Marie Curie Research Fellow, Public Governance Institute, KU Leuven and Senior Research Fellow, Ragnar Nurkse Department of Innovation and Governance, Tallinn University of Technology. Corresponding author: veiko.lember@kuleuven.be.

Rainer Kattel, Professor at UCL and Research Professor at Ragnar Nurkse Department of Innovation and Governance, Tallinn University of Technology.

Piret Tõnurist, Research Fellow, Ragnar Nurkse Department of Innovation and Governance, Tallinn University of Technology and Policy Analyst at the OECD. 


\section{Introduction}

Technology is clearly a critical factor in lives of organizations. We know from private sector research how companies have changed their work organization due to different technologies (historical overview in Perez 2002) and especially more recently by ICT (e.g., flat hierarchies, platform-based services, peer production) (Trist 1981, Barley 1990, Dunleavy et al 2006, Leonardi and Barley 2010). There is increasing pressure for public sector to do the same - arguably public sector innovation (Osborne and Brown 2013), digital-era governance (Dunleavy et al 2006), e-government (Janssen and Estevez 2013) and smart city (Townsend 2013) discourses reflect such pressures. Nevertheless, there seems to be little evidence from public organizations (Pollitt 2012, Margetts and Dunleavy 2013). While majority of the existing studies on digital technologies in public sector have focused around different enablers and barriers without well-defined theoretical body (Janssen and Estevez 2013), only very few studies have tried to unpack the deeper mechanisms that shape the long-term transformation of public sector (e.g. Fountain 2001, Dunleavy et al 2006, Gil-Garcia and MartinezMoyano 2007). The existing studies have so far mostly concentrated on various parts of what in evolutionary terms can be summarized as variety creation process (e.g. how organizations discover, learn and implement new technologies) without systematically taking into account the complex feedback and selection forces that influence the evolution of technological change in public sector (i.e., why organizations discover, learn and implement new technologies).

We propose to analyze the technological impact on public sector performance through a new concept of technological capacity. In our view, technological capacities are increasingly critical elements of administrative capacity. Thus, we develop from the bottom-up further the existing concept of administrative capacity, and as there are hardly any studies on technology and public organizations, we start from the micro-level (while next studies could look also at state and especially policy capacities). We argue that technological capacity is formed through co-evolutionary selection and feedback processes between public organizations, markets, policy networks and citizens. 
Thus, we aim to take the existing literature a step further and explore how the technology-driven internal variety creation processes (organizational behavior) in public sector are molded by "the interactive mechanism through which selection occurs" (Dosi and Nelson 1994 p. 154). In this context, the article will tackle two inter-related research questions. First, how does technological change influence administrative capacity in public organizations? Second, why and how technological change takes place in public sector? In order to answer the first research question, we explore what happens within public organizations when they adopt or develop new technologies. To address the second research question, we study why do some organizations adopt or develop new solutions and others not.

When it comes to technology and public administration, Estonia can be considered highly suitable for an exploratory case-study. Estonia has been associated internationally with a strong e-state profile (Kalvet 2012, Margetts and Naumann 2017). Famous for its e-government developments, particularly electronic ID-card and secure data exchange architecture (so-called X-Road ${ }^{1}$ ), Estonia has successfully launched one of the leading solutions of its kind globally. Near universal diffusion of the electronic ID-card among the citizens means that almost all personal income taxes are declared online, nearly all medical prescriptions are issued electronically, and other e-services cover a wide range of areas (central and local governments offer some 1500+ services fully on-line). More recently, the government of Estonia launched an ambitious e-residency program aiming at attracting through public service exports some 10 million new e-residents globally (Estonia has 1.3 million actual residents) who can take advantage of the e-government infrastructure. The country has also proposed to partner up with Uber to use Estonian e-government infrastructure to fully automate the tax declaration process for Uber drivers globally. ${ }^{2}$ At the same time, Estonia is also internationally known for its exceptionally high social trust towards e-government solutions, where privacy-related

\footnotetext{
${ }^{1}$ See: https://e-estonia.com/component/x-road/.

${ }^{2}$ See: http://www.emta.ee/eng/etcb-and-uber-collaborate-seeking-solutions-development-sharing-economy
} 
issues have very little impact on policy debates and where ICT has become one of the building blocks of national branding. In addition, the last decade of public sector reforms has been implemented under the radical austerity conditions (Kattel and Raudla 2013) that has provided additional strong impetus for technology-intensive reforms. Thus, we aim to test our framework in a highly supportive digital environment where one would expect to see rapid evolution of technological capacities across the public sector.

We test the proposed conceptual framework with nine within-case studies from Estonia: postal service, emergency medical service, public transportation services, welfare services, social insurance services, employment services, tax collection service, internal security services, and e-residency. We aim to show that in each within-case, new technological solutions impacted how administrative capacities evolved in the organizations responsible for these developments, and how their technological capacity progressed.

The first section of the article introduces the concept of technological capacities. The second section provides an overview of the selected case studies. The final section concludes the paper by discussing the main implications from the study.

\section{Theoretical discussions: The evolution of technological capacity of public sector}

Complex and sophisticated technologies (from medical technologies to predictive policing) have clearly changed what kind of services public sector organizations can deliver and how the public service delivery is organized (Pollitt 2012). Increased life-expectancy, reduced crime-rates, shortened service delivery time, increased legitimacy or trust of governments and similar positive added public values are often claimed to result from application of new technologies. Yet, an important gap in theory relates to the linkages between introducing new technological solutions and organizational performance. In order to go beyond the traditional efficiency/productivity approach that is bound to remain handicapped in this context (already Baumol 1967), we propose to focus on the evolution of the technological capacities in public sector. We define technological capacity as an 
ability to explore, develop and/or adapt new technological solutions in public service design, delivery and evaluation. In that sense, we build on the earlier work on administrative capacities, which we understand as the delivery of tasks within a given framework of resources (human, financial, relational) and authority (reputation, coordination practices, politics) (see also Painter and Pierre 2005, Karo and Kattel 2016).

In order to capture technological capacities of public sector organizations, and their impact and evolution, we need to understand what mechanisms drive speed, sophistication and direction of technological developments and how it materializes through change in work organization. Technology changes the role of bureaucracy and work organization in many ways. This process is, however, not entirely deterministic, i.e. technological advances do not come with blueprints for how organizations should or will adapt them (Nelson and Winter 1982, Orlikowsky 1992, Fountain 2001, Leonardi and Barley 2010). Building on evolutionary economics, innovation is foremost an organizational process (Coriat and Weinstein 2002), where organizations, their routines and capabilities co-evolve with technology while being influenced by the wider institutional context (i.e. innovation systems) (Nelson and Winter 1982). Organizational routines (i.e. regular and persistent operating procedures) determine the ability of an organization to undertake and master specific (novel) tasks (Teece 2009). That is, routines are repositories of organizational capabilities and how these are accumulated, transferred and applied (Zollo and Winter 2002). Importantly, these routines are sticky and path-dependent, but not static as they change over time. The evolution of routines in organizations is on the one hand related to internal search capabilities and on the other to a specific selection and feedback environment that all influence how organizations learn and make choices (Teece 2009, also March 1991). Organizational choice is, thus, never fully autonomous (Coriat and Weinstein 2002) - the evolution of underlining technological capacities does not depend only on internal structures and processes of organizations, but also on that of key partners, and how these networks are structured by rules and regulations. 
To summarize, first, capacities are best expressed and studied through routines; and second, there are three key elements that one needs to take into account when conceptualizing the evolution of technological capacities as routines in public sector: internal routines, external routines, and selection and feedback environments. Following Dosi and Nelson (1994), internal routines reflect a mix of public sector organizational standard procedures from procurement and recruitment to financial and implementation practices, while external routines reflect practices of key partners. These internal and external technological capacities are intrinsic to the process of technology development. As indicated, these technological capacities evolve by being influenced by external environment that operates as a selection and feedback mechanisms (re-enforcing or discouraging specific routines). The selection and feedback mechanisms are, thus, extrinsic to the process of technological development. They re-enforce what the organization has already learned and through the organizational level depositories of knowledge, guide future learning processes both on the individual and organizational level (Crossan et al. 1999). In the public sector context, one can distinguish between four selection environments: citizen feedback, market, policy network and hierarchical politico-administrative processes. ${ }^{3}$

Table 1 summarizes the presented framework.

\footnotetext{
${ }^{3}$ Gil-Garcia and Martinez-Moyano (2007) refer to citizens, businesses, other governmental units and political stakeholders as key sources of feedback and pressure in e-government; Dunleavy et al (2006) emphasize the role of citizens, businesses and other sectors on hierarchical behavior; Cordella and Willcocs (2010) specifically look at market behavior; and Fountain (2001) analyses the role of networks.
} 
Table 1: Technological routines and selection mechanisms in public sector (Source: authors)

\begin{tabular}{|l|l|l|l|l|}
\hline & \multicolumn{4}{|c|}{ Selection mechanisms through: } \\
\hline $\begin{array}{l}\text { Technological } \\
\text { change is } \\
\text { affected by and } \\
\text { affects: }\end{array}$ & Citizens/users & Market type behavior & Networks & Hierarchical behavior \\
\hline $\begin{array}{l}\text { Internal } \\
\text { technological } \\
\text { routines }\end{array}$ & $\begin{array}{l}\text { E.g. citizens' } \\
\text { expectations and needs } \\
\text { may change due to } \\
\text { technology }\end{array}$ & $\begin{array}{l}\text { E.g. procurement } \\
\text { practices can influence } \\
\text { the nature of } \\
\text { competition and } \\
\text { technological } \\
\text { advancement }\end{array}$ & $\begin{array}{l}\text { E.g. access to policy } \\
\text { design might be } \\
\text { conditioned by internal } \\
\text { routines }\end{array}$ & $\begin{array}{l}\text { E.g. use of predictive } \\
\text { mobility models might } \\
\text { enable better policing } \\
\text { and/or increase } \\
\text { organizational } \\
\text { productivity and/or } \\
\text { change organizational } \\
\text { structures }\end{array}$ \\
\hline $\begin{array}{l}\text { External } \\
\text { technological } \\
\text { routines }\end{array}$ & $\begin{array}{l}\text { E.g. citizens' } \\
\text { technological skills may } \\
\text { affect government } \\
\text { legitimacy }\end{array}$ & $\begin{array}{l}\text { E.g. monopolistic skills } \\
\text { might drive prices for } \\
\text { new solutions very high } \\
\text { (healthcare e.g.) }\end{array}$ & $\begin{array}{l}\text { E.g. skills of partners, } \\
\text { expectations might } \\
\text { change policy contents }\end{array}$ & $\begin{array}{l}\text { E.g. state audit's } \\
\text { evaluation models } \\
\text { might deem the above } \\
\text { policing model too } \\
\text { expensive }\end{array}$ \\
\hline
\end{tabular}

These selection environments exist in parallel in co-evolutionary manner (Dosi and Nelson 1994); i.e., they influence each other and vary in their importance vis-à-vis specific public sector activity. The central element of the selection environment is how external stakeholders learn about, perceive, evaluate and act upon innovations (Nelson and Winter 1982). Crucially, in public sector these linkages are often contested and much more complex than in private sector (Bozeman 2002). In cases where impacts of public sector performance are difficult to measure, the feedback on new technologies depends heavily on stake-holders' value-based perceptions (e.g., seeing individual or collective gains; Taylor 2016) as well as on political, ideological or cognitive frameworks that these stakeholders apply when confronting or applying technologies (Orlikowski 1992). Whereas in some other cases where the impact is easy to measure and communicate, the feedback tends to be more direct in its nature (e.g. if fiscal profit/loss or increased user participation as indicators for technological performance - e.g. Hood and Dixon 2015). 
Importantly, different selection environments can be in conflict with each other (Dosi and Nelson 1994). For instance, increased big data and real-time monitoring capacity of public sector organizations may lead to more efficient and effective public services (e.g. in transportation) and thus reinforce change in internal technological routines and/or it may create positive market spillovers (e.g. new niche markets or export revenues) and thus reinforce external technological routines. But it may also evoke strong skepticism among some stakeholders on the basis of, e.g., excessive surveillance and profiling, which in turn can cause outright protests, reduce trust towards the government and limit the further use of such technologies. In addition, autonomy of an organization to deviate from and challenge the existing characteristics of wider institutional settings is important (Coriat and Weinstein 2002, Tõnurist et al 2017). As institutional settings can both constrain as well as provide resources and opportunities for organizations, the variety generation in society happens when organizations using different systems of rules come into conflict with other systems of rules, which eventually may lead to the de-legitimization of old norms and institutionalization of new rules (Coriat and Weinstein 2002). This means that both the relative importance of different feedback environments as well as interaction patterns between internal and external stakeholders can change as a result of conflicts between actors' use of rules of the game. ${ }^{4}$

In order to simplify how technological capacities of public sector (internal technological routines) evolve, we propose to analyze them on a (more/less) dynamic-static continuum. Thus, dynamic technological capacities are expressed through fundamental and rapid changes to existing administrative capacities in a particular organization (usually assuming the presence of transformational leadership, see Bass and Riggio 2006, and a cumulative change in structure, division

\footnotetext{
${ }^{4}$ There are many other possible intervening factors to public sector change, e.g., overall administrative culture, public sector reform ideas etc (Pollitt and Bouckaert 2011), but these can be seen as part of the market, hierarchy, network or citizen relationships. The point here is to understand the role of technology in public sector change and not to describe all the factors individually.
} 
of tasks, management practices, power relations etc., see Leonardi and Barley 2010); static technological capacities are in turn expressed through relatively unchanged administrative capacities leading to a continuation of existing evolutionary trajectories. Some organizations are neither dynamic nor static, and some departments within static organizations can be dynamic, and vice versa. Importantly, organizations with dynamic technological capacities manage to solve March's dilemma of explore and exploit, or what could also be called the ambidexterity dilemma in public sector: how to introduce radical new technological solutions, while providing for services prescribed by laws and regulations (March 1991, O'Reilly and Tushman 2008).

Based on the discussion above we formulated four groups of theoretical expectations that enable us to explore the research questions (Table 2). 
Table 2: Theoretical expectations (Source: authors)

\begin{tabular}{|c|c|c|}
\hline $\begin{array}{l}\text { Feedback and } \\
\text { selection } \\
\text { environments }\end{array}$ & Theoretical expectations & Sources \\
\hline \multirow{3}{*}{$\begin{array}{l}\text { 1. Citizens' } \\
\text { and user } \\
\text { feedback: }\end{array}$} & $\begin{array}{l}\text { a) Rapid diffusion of country-wide e-infrastructure and e-services (e.g. electronic banking) lowers the barriers of entry for } \\
\text { new public e-services and technological solutions. If this is the case, we can expect citizens to be open to new solutions. }\end{array}$ & Margetts and Naumann 2017 \\
\hline & $\begin{array}{l}\text { b) Privacy concerns among citizens functions as a key selection mechanism in the evolutionary process of public sector } \\
\text { technological solutions. We expect rapid technological change in public organizations where privacy concerns have little } \\
\text { impact. }\end{array}$ & Kitchin 2016 \\
\hline & c) Rapid technological change happens if user behavior can be associated with technological upgrade. & Brown et al 2014 \\
\hline \multirow[t]{3}{*}{$\begin{array}{l}\text { 2. Market } \\
\text { feedback: }\end{array}$} & $\begin{array}{l}\text { a) Public organizations are tasked with delivery of universal services and accordingly focus on exploiting existing } \\
\text { technological solutions rather than experimenting with new ones. As most of the technological solutions in public sector } \\
\text { are insourced from private sector, we can expect thus procurement to be key in absorbing technological advancements } \\
\text { into public organizations. }\end{array}$ & $\begin{array}{l}\text { March 1991; Dunleavy et al } \\
2006\end{array}$ \\
\hline & b) We expect to see slow rate of technological change where market capabilities are fragmented. & Dunleavy et al 2006; Na 2016 \\
\hline & $\begin{array}{l}\text { c) We expect to see rapid rate of technological change where public procurement leads to the creation of new market } \\
\text { capabilities, niche markets or similar positive economic spillovers. }\end{array}$ & Lember et al 2015 \\
\hline \multirow[t]{2}{*}{$\begin{array}{l}\text { 3. Network } \\
\text { feedback: }\end{array}$} & $\begin{array}{l}\text { a) Public policies are always carried out in a wider institutional context where various policy stakeholders influence both } \\
\text { policy choices as well as implementation. Thus, we expect stakeholder engagement practices to have significant influence } \\
\text { over technological change in public sector. }\end{array}$ & Fountain 2001 \\
\hline & $\begin{array}{l}\text { b) Relatedly, we expect the degree of political power these stakeholders have in policy networks to influence the evolution } \\
\text { of technological capacities in public sector depending if the dominant stakeholders possess high or low level technological } \\
\text { routines. }\end{array}$ & Fountain 2001 \\
\hline \multirow[t]{5}{*}{$\begin{array}{l}\text { 4. Hierarchical } \\
\text { feedback: }\end{array}$} & $\begin{array}{l}\text { a) In the decade-long austerity context, we can expect that austerity politics plays important role in driving technological } \\
\text { solutions as they are seen by political and business elites to potentially boost productivity in public sector and enable } \\
\text { emerging countries' quests to become global leaders in e-government solutions. }\end{array}$ & Dunleavy et al 2006 \\
\hline & $\begin{array}{l}\text { b) Austerity politics can be seen as important factor for both centralization of technological services within public sector } \\
\text { organizations and increased outsourcing of developing new technological solutions. }\end{array}$ & $\begin{array}{l}\text { Dunleavy et al 2006; Cordella } \\
\text { and Willcocs } 2010\end{array}$ \\
\hline & $\begin{array}{l}\text { c) We can expect in such context that increased outsourcing of technological solutions and efficiency driven procurement } \\
\text { practices weaken internal technological capacities. }\end{array}$ & $\begin{array}{l}\text { Dunleavy et al 2006; Cordella } \\
\text { and Willcocs } 2010\end{array}$ \\
\hline & $\begin{array}{l}\text { d) Many if not most public sector tasks are implemented in the context of complex legacy systems. As interoperability of } \\
\text { data systems and platforms is a key issue of today's public sector technological change we expect to see more rapid } \\
\text { technological change in case of simple as well as newly emerging services. }\end{array}$ & $\begin{array}{l}\text { Brown et al 2014; Fountain } \\
2001\end{array}$ \\
\hline & $\begin{array}{l}\text { e) Many new technological solutions have both internal (within public sector) and external impact; we can expect that } \\
\text { latter is often not conceptualized or measured properly as auditing, measurement and fiscal procedures tend to focus on } \\
\text { concrete organizations and activities. }\end{array}$ & Kitchin 2016 \\
\hline
\end{tabular}




\section{Methodology and Description of the Case}

Our aim is to explain through an evolutionary framework how technological capacities evolve in a supportive public sector context by comparing results from nine within-case studies representing different Estonian public sector contexts: postal service, emergency medical service, public transportation services, welfare services, social insurance services, employment services, tax collection service, internal security services, and e-residency. Thus, within-cases with different speed of technological change in respective sectors, types of organizations in terms of their autonomy and feedback systems were selected in order to collect rich, bottom-up data. The within-case method was selected as it is highly suitable for providing exploratory insights and preliminary explanations on an emerging topic assuming intimate and high-level knowledge of the studied context (Paterson 2012). We compare the patterns emerging from the different within-cases against each other as well as against the theoretical hypotheses derived from the literature. Table 3 summarizes the selection of within-cases.

Table 3: Overview of case studies (Source: authors)

\begin{tabular}{|l|l|l|l|l|}
\hline & $\begin{array}{l}\text { Technology } \\
\text { intensiveness } \\
\text { of introduced } \\
\text { changes }\end{array}$ & $\begin{array}{l}\text { Organizational } \\
\text { autonomy }\end{array}$ & $\begin{array}{l}\text { Complexity of } \\
\text { feedback } \\
\text { system }\end{array}$ & Why interesting? \\
\hline $\begin{array}{l}\text { Emergency } \\
\text { medical service }\end{array}$ & Low & Moderate & Moderate & $\begin{array}{l}\text { Highly specialized and } \\
\text { professionalized service }\end{array}$ \\
\hline $\begin{array}{l}\text { Road and } \\
\text { transport } \\
\text { administration }\end{array}$ & Moderate & Moderate & Low & $\begin{array}{l}\text { Divisional structure enables in- } \\
\text { house comparisons }\end{array}$ \\
\hline $\begin{array}{l}\text { Tax and customs } \\
\text { Police }\end{array}$ & High & Moderate & Low & $\begin{array}{l}\text { Classic example in technology and } \\
\text { public administration; technological } \\
\text { frontrunner }\end{array}$ \\
\hline $\begin{array}{l}\text { Employment } \\
\text { services }\end{array}$ & Moderate & Moderate & Moderate & $\begin{array}{l}\text { Epitomizes how organizational tasks } \\
\text { have changed over longer period of } \\
\text { time }\end{array}$ \\
\hline Welfare services & Low & Moderate & High & $\begin{array}{l}\text { Classic welfare state service, } \\
\text { tax collection) }\end{array}$ \\
\hline Postal service & High & High & Low services (e.g. \\
\hline
\end{tabular}




\begin{tabular}{|l|l|l|l|l|}
\hline Social insurance & Moderate & Moderate & Moderate & Fundamental welfare state function \\
\hline E-residency & High & Low & Low & $\begin{array}{l}\text { Fully technology-enabled new } \\
\text { public service; start-up government; } \\
\text { public-service export }\end{array}$ \\
\hline
\end{tabular}

The data was obtained from document analyses as well as 19 semi-structured interviews with the representatives of the respective organizations (mostly heads of organizations, but in some cases heads of development or technology units; 14 interviews), public organizations responsible for ICT infrastructure development in Estonia (4) and organization responsible for auditing these developments. We first collected data on overall technological developments in all selected organizations and then, secondly, obtained more specific information on changes in internal administrative routines. For the latter, we asked the interviewees about technology-driven changes in structure, division of tasks and management, developments towards real-time and automated service provision, integration of services (state level infrastructure as well as inter-organizational collaboration), user-driven service design, and also about in-house production vs externalization of technology development. We also asked the interviewees about overall impact of technological change on organizational performance (productivity, change in core tasks, etc.).

In order to apply the conceptual framework for explaining and understanding change in technological capacities, we also obtained information on the feedback and selection environments. We asked the respondents about the sources of technological and related organizational change, the drivers and barriers of that change, the role of external stakeholders, the feedback characteristics, and the quality of inter-organizational interactions.

The main dynamics in technological capacities in the studied cases are summarized in Table 4. 
Table 4: The main dynamics between technological change and administrative capacities in the studied cases (Source: authors)

\begin{tabular}{|c|c|c|c|c|c|}
\hline & $\begin{array}{l}\text { Main technological } \\
\text { innovations }\end{array}$ & $\begin{array}{l}\text { Change in } \\
\text { technological } \\
\text { capacity }\end{array}$ & Main feedback dynamics & Change in internal routines & Change in external routines \\
\hline $\begin{array}{l}\text { Emergency } \\
\text { medical service }\end{array}$ & $\begin{array}{l}\text { GPS assisted transportation } \\
\text { planning }\end{array}$ & Static & $\begin{array}{l}\text { Hierarchical; technology of } \\
\text { secondary importance among } \\
\text { powerful policy network } \\
\text { stakeholders }\end{array}$ & $\begin{array}{l}\text { More centralized decision-making due } \\
\text { to increased data collection } \\
\text { capabilities }\end{array}$ & $\begin{array}{l}\text { Gradual upgrade in private providers' } \\
\text { technological capabilities }\end{array}$ \\
\hline $\begin{array}{l}\text { Road and traffic } \\
\text { administration }\end{array}$ & $\begin{array}{l}\text { Automated traffic and road } \\
\text { monitoring; do-it-yourself e- } \\
\text { services }\end{array}$ & Static & $\begin{array}{l}\text { Users' uptake as key selection } \\
\text { mechanism; hierarchical feedback } \\
\text { (productivity concerns) }\end{array}$ & $\begin{array}{l}\text { Selected task automatization and } \\
\text { reallocation to citizens as well as } \\
\text { geographically leading to limited } \\
\text { productivity increase }\end{array}$ & $\begin{array}{l}\text { Change in selected service consumption } \\
\text { (from physical to digital) causing radical } \\
\text { productivity increase (time-savings) }\end{array}$ \\
\hline $\begin{array}{l}\text { Tax and } \\
\text { customs }\end{array}$ & $\begin{array}{l}\text { Automated services and data } \\
\text { exchange; data analytics } \\
\text { based services; service as } \\
\text { platform }\end{array}$ & Dynamic & $\begin{array}{l}\text { Technology triggers positive } \\
\text { feedback in all selection } \\
\text { environments; internal and external } \\
\text { productivity increase clearly evident }\end{array}$ & $\begin{array}{l}\text { Data driven change and } \\
\text { reprioritization in core tasks leading } \\
\text { to radical productivity increase }\end{array}$ & $\begin{array}{l}\text { Digital service consumption and increase in } \\
\text { partners' technological skills }\end{array}$ \\
\hline Police & $\begin{array}{l}\text { GPS-assisted transportation } \\
\text { planning; digitized back-office } \\
\text { services and real-time } \\
\text { information access (e-police) }\end{array}$ & Static & $\begin{array}{l}\text { Technology does not trigger strong } \\
\text { positive feedback loops in any } \\
\text { selection environments }\end{array}$ & $\begin{array}{l}\text { Digitalization of some existing } \\
\text { routines; more centralized decision- } \\
\text { making due to increased data } \\
\text { collection capabilities }\end{array}$ & $\begin{array}{l}\text { Very limited change in service } \\
\text { consumption, new capabilities among } \\
\text { selected private sector partners }\end{array}$ \\
\hline $\begin{array}{l}\text { Employment } \\
\text { service }\end{array}$ & $\begin{array}{l}\text { Digitized back-office services } \\
\text { and real-time information } \\
\text { access; technology-enabled } \\
\text { do-it-yourself services }\end{array}$ & Static & $\begin{array}{l}\text { Signals from hierarchical feedback } \\
\text { mixed (high complexity leads to high } \\
\text { coordination costs, while } \\
\text { productivity concerns central) }\end{array}$ & $\begin{array}{l}\text { Digitalization of some existing } \\
\text { routines; more centralized decision- } \\
\text { making due to increased data- } \\
\text { collection capabilities }\end{array}$ & $\begin{array}{l}\text { Very limited change in service consumption } \\
\text { and technological skills of partners }\end{array}$ \\
\hline $\begin{array}{l}\text { Welfare } \\
\text { services }\end{array}$ & $\begin{array}{l}\text { Digitized back-office services } \\
\text { and real-time information } \\
\text { access }\end{array}$ & Static & $\begin{array}{l}\text { Technology does not trigger strong } \\
\text { positive feedback loops in any } \\
\text { selection environments ("cost } \\
\text { disease") }\end{array}$ & $\begin{array}{l}\text { Strategic and back-office decision- } \\
\text { making centralized due to increased } \\
\text { data-collection capabilities; core } \\
\text { service provision more de-centralized }\end{array}$ & No direct impact \\
\hline Postal service & $\begin{array}{l}\text { From traditional postal } \\
\text { services to semi-automated } \\
\text { parcel services; do-it-yourself } \\
\text { service provision }\end{array}$ & Dynamic & Strong market and citizens' feedback & $\begin{array}{l}\text { Technology induced radical change in } \\
\text { business model; increase in } \\
\text { productivity due to economies of } \\
\text { scale; more flat organization }\end{array}$ & $\begin{array}{l}\text { Change in service consumption (incl. do-it- } \\
\text { yourself); rapid change in suppliers' } \\
\text { technological routines }\end{array}$ \\
\hline $\begin{array}{l}\text { Social insurance } \\
\text { services }\end{array}$ & Digitized data exchange & Static & $\begin{array}{l}\text { Hierarchical feedback gives mixed } \\
\text { signals (public-sector complexity } \\
\text { leads to high coordination costs, } \\
\text { while productivity concerns central) }\end{array}$ & $\begin{array}{l}\text { Digitalization of some existing } \\
\text { routines; more centralized decision- } \\
\text { making due to increased data- } \\
\text { collection capabilities }\end{array}$ & $\begin{array}{l}\text { Low capability in private sector to tackle } \\
\text { complex technological challenges }\end{array}$ \\
\hline E-residency & $\begin{array}{l}\text { Digital-ID-enabled access for } \\
\text { foreign citizens to public and } \\
\text { private services in Estonia }\end{array}$ & Dynamic & $\begin{array}{l}\text { Strong positive user, policy network } \\
\text { and hierarchical impact (national } \\
\text { prestige) }\end{array}$ & $\begin{array}{l}\text { Entirely new routines; collaborative } \\
\text { governance and economies of scale as } \\
\text { key logics }\end{array}$ & $\begin{array}{l}\text { Limited change so far; potentially radical } \\
\text { change }\end{array}$ \\
\hline
\end{tabular}




\section{What happens within public organizations when they adopt or develop new technologies?}

Estonia has an international image of being one of the front-runners in using modern technology in providing public services. Yet, the empirical evidence gathered in this study demonstrates that beyond introducing a well-functioning basic data exchange infrastructure the public sector has experienced an uneven evolution of technology capacities. Table 4 illustrates that nine cases fall into two categories: 1) dynamic organizations/services with strong and dynamically evolving technological capacities ( 3 cases); 2 ) static organization/services with low and static technological capacities (6 cases). In dynamic organizations/services - providing tax, postal and e-residency services administrative capacities have rapidly increased because of technological change. All these three organizations are distinctively different in how they organize their core tasks today compared to only five or ten years ago. These organizations are also ambidextrous: they manage to introduce new radical technological solutions (e.g. predictive analytics in case of tax authority, platform-based service logic of e-residency and entirely new business model of postal services) and keep providing services required by laws and regulations while improving service provision.

Correspondingly, it can be seen that the introduction of new technologies cumulatively leads to both changes in work tasks as well as what skills the staff is expected to possess. In the Tax Board the increasing data analytical capacities have changed how certain tasks are carried out (e.g., controlling has changed from collecting information to analyzing the existing data; fraud detection is gradually deprioritized over service provision such as optimizing border crossing, automating repetitive tax declarations and payments; and service provision relying heavily on machine-to-machine interactions) and what skills are needed to carry out those tasks (from communication and information collection to data analytical skills and increasingly big data skills). In case of e-residency the adopted technology has forced the responsible public authorities to opt for a collaborative and agile governance mode: the e-residency as a service can succeed only if existing and new services provided by external partners are successfully integrated with the e-residency platform. The organization is open to rapid learning (e.g., reviewing, revising and changing use cases) and 
experimenting (e.g., hackathons). Relatedly, the staff involved all possess high level digital and service design skills; organizational culture is formed around key performance indicators, data visualization and business case thinking. In case of the postal service, the once cumbersome public monopoly delivering mail has shifted its focus on digital processes throughout by focusing on growth areas driven by technological change. All three organizations are or have been led by charismatic leaders within organization (e.g., head of Tax and Customs Board rose through the ranks from frontline border official to the top of the agency) or within closer network (in case of e-residency the Deputy-Secretary General in Ministry of Economic Affairs and Communications was before a successful IT businessman).

All other cases (static organizations/services) represent more typical public services and here we see much slower change in technological capacities. These are organizations characterized by slow rather than rapid change in technological routines and which have mostly started to digitize their support functions (e.g. data exchange and information management), while occasionally experimenting with new technological solutions in carrying out their core tasks. This has led to changes in allocation of tasks (geographically) and responsibilities (structurally with less middle managers) in, e.g., welfare services case. However, overall, technology has had limited impact on how their administrative capacities have changed. The interviewees acknowledged that in general there is either not much technological "innovations" happening or much more innovations could happen compared to today's situation.

Estonia has a crucial difference compared to other countries as the X-road system is considered as an effective generic data exchange platform (Margetts and Naumann 2017). Nevertheless, our cases show that dynamic and static organizations make different use of technology-facilitated interorganizational collaborations. Apart from some basic support systems for personnel management and similar functions, organizationally tailor-made IT-systems and related unique service provision systems are the norm in Estonia. Even if some organizations already possess certain technological capacities that other organizations need, there is very limited inter-organizational collaboration or 
service integration in terms of shared service provision platforms. Several interviewees pointed out that data-based collaboration threatens to re-allocate power within public sector, which has made many organizations cautious. The same is true for open data use - there is very little use of open data, although this has been also a conscious policy decision of the central ICT policy-makers (ibid.). This seems to have a strong impact on static organizations, while the dynamic organizations tend to be more open towards collaboration. For example, e-residency was developed as an integrative platform right from the start, meaning the entire idea of the service is to create value by bringing together different public and private services and organizations that e-residents may find useful. The tax authority aims at providing their solutions as service platforms for external stakeholders (e.g. automated accounting services for small enterprises or global tax payment solution for Uber). Technological capacities enable the dynamic organizations to act selectively. That is, they have the ability to discriminate against or ignore users with low-level technological skills. Austerity-driven political context has significantly empowered the Tax Board and it is in a position where it can dictate to citizens, but especially private firms, to upgrade their technological skills and adjust their technological processes even if they are reluctant to do so due to associated costs. ${ }^{5}$ As parcel services do not need to be supplied universally, it means that the state-owned firm can concentrate on more technology-prone users and partners, while using the profits generated through their new business model to subsidize the loss-making universal postal service division. In case of e-residency,

\footnotetext{
${ }^{5}$ For example, in 2014 it became compulsory for companies to declare over 1000 EUR bills. While there were claims of increased administrative burden to companies, the Tax Board provided a machine-to-machine solution to firms to declare the bills straight from their accounting software. It took only a month to understand from increased VAT revenues that the technology investments paid off. According to an interviewee, the same happened in the electronic employment register case which caused the black market in construction to go down from $27 \%$ to $7 \%$ in less than a year.
} 
the main e-service users are highly educated foreign individuals and companies, making this service highly exclusive by design.

\section{Why do some organization adopt or develop new technological solutions and others not?}

Following our framework, we would expect that different feedback and selection mechanisms feed into the dynamic or static change in administrative capacities in the public sector. Table 5 pulls together our expectations and reflects the evolution of technological capacities in Estonian public sector. In all four selection and feedback mechanisms there is a marked difference between dynamic and static organizations; although, some static organizations have dynamic elements, the composition of these selection mechanisms seem to determine if new technological solutions are developed.

Rapid diffusion of e-infrastructure and almost non-existing impact of privacy-related issues have clearly lowered the barrier of entry for citizens and have thus played a vital role in the evolution of technological capacities in both types of services. However, both aspects should be still considered as necessary, but not sufficient pre-conditions for rapid developments in technological capacities.

Firstly, citizen/user feedback has played a key role in dynamic services (change in fiscal revenues, uptake of e-residency and profit/loss calculus in parcel services), while in most other cases it has played either a moderate (road authority, emergency medical services, social insurance, employment, police) or almost no role at all (welfare services for mentally disabled people). The latter case is illustrative: there are many promising new technologies available for treatment and rehabilitation, yet there exist hardly any interest or pressure from the relatives of the patients to develop these services as it is still the human component in their core tasks that matters most. 
Table 5. Importance of feedback mechanisms (Source: authors)

\begin{tabular}{|c|c|c|}
\hline \multirow{3}{*}{ 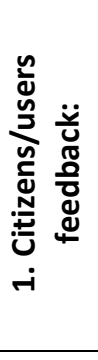 } & a) Rapid diffusion of e-infrastructure makes citizens more open to new solutions. & $\begin{array}{l}\text { Corroborated: the wide adoption of the e-ID } \\
\text { card, positive influence significant in dynamic } \\
\text { organizations }\end{array}$ \\
\hline & $\begin{array}{l}\text { b) Privacy concerns among citizens function as a key selection mechanism: rapid } \\
\text { technological change in public organizations where privacy concerns have little impact. }\end{array}$ & Not corroborated: privacy concerns not identified \\
\hline & $\begin{array}{l}\text { c) Rapid rate of technological change where user behavior can be explicitly associated with } \\
\text { technological upgrade. }\end{array}$ & Corroborated: dynamic organizations \\
\hline \multirow{3}{*}{ 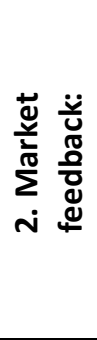 } & $\begin{array}{l}\text { a) Public procurement practices influence the absorption of technological advancements } \\
\text { into public sector. }\end{array}$ & Corroborated partly: mixed evidence across cases \\
\hline & b) Slow rate of technological change where market capabilities are fragmented. & Corroborated: static services \\
\hline & $\begin{array}{l}\text { c) Rapid rate of technological change where public procurement leads to the creation of } \\
\text { new market capabilities, niche markets or similar positive economic spillovers. }\end{array}$ & Not corroborated: only in limited cases \\
\hline \multirow{2}{*}{ 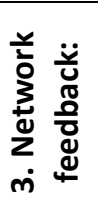 } & $\begin{array}{l}\text { a) Stakeholder-engagement practices have significant influence on technological change in } \\
\text { the public sector. }\end{array}$ & $\begin{array}{l}\text { Corroborated: significant influence on e- } \\
\text { residency and tax services }\end{array}$ \\
\hline & $\begin{array}{l}\text { b) The degree of political power of stakeholders influences the evolution of technological } \\
\text { capacities in the public sector depending on whether the dominant stakeholders possess } \\
\text { dynamic or static technological routines. }\end{array}$ & $\begin{array}{l}\text { Corroborated: strong influence on dynamic } \\
\text { organizations (also partly on static, e.g. road } \\
\text { administration) }\end{array}$ \\
\hline \multirow{5}{*}{ 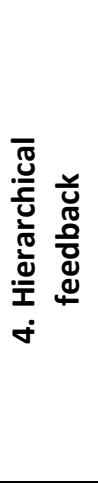 } & a) Austerity politics plays an important role in driving technological solutions. & $\begin{array}{l}\text { Corroborated partly: strong rhetoric in all cases, } \\
\text { the impact varies between cases }\end{array}$ \\
\hline & $\begin{array}{l}\text { b) Austerity politics is an important factor for both centralization of technological services } \\
\text { within public sector organizations and increased outsourcing of developing new } \\
\text { technological solutions. }\end{array}$ & Corroborated: static services \\
\hline & $\begin{array}{l}\text { c) The increased outsourcing of technological solutions and efficiency-driven procurement } \\
\text { practices weaken internal technological capacities. }\end{array}$ & $\begin{array}{l}\text { Corroborated partly: some static services } \\
\text { (welfare, social insurance, police) }\end{array}$ \\
\hline & d) More rapid technological change in case of simple as well as newly emerging services. & Corroborated: dynamic services \\
\hline & $\begin{array}{l}\text { e) External impact is often not conceptualized or measured properly, as auditing, } \\
\text { measurement and fiscal procedures tend to focus on concrete organizations and activities. }\end{array}$ & $\begin{array}{l}\text { Corroborated partly: stronger impact on static } \\
\text { services }\end{array}$ \\
\hline
\end{tabular}


The difference between dynamic and static organizations indicate that the easier it is for a public organization to measure and thus communicate the performance improvements, the quicker the reactions from users feed back into the development of technological capacities. While all studied dynamic organizations can directly link their technological performance to productivity change measured (near) real-time and in monetary terms, for static organizations it is mostly the time saved for users (citizens) that can create positive feedback loops and enable further investments into technological capacities. For example, the Road Authority managed to cut the issuing of driving licenses from two weeks to two days without any need to visit the office physically, providing a strong case for further ICT investments (currently $40 \%$ of services are e-services). In many occasions, however, citizen feedback remains a weak signal as time saved for citizens is either too insignificant to be noticed (e.g. emergency call center aims at reducing the average response to emergency calls for extra couple of seconds) and/or comes with increasing costs for service organization as investments and maintenance of ICT systems is costly. For emergency medical service, police, rescue and other internal security and health care providers the added value comes mostly if technology enables real-time monitoring and shortened decision-making processes in order to save lives, and thus includes no direct feedback from citizens. Trust surveys, recommendation indices and similar proxy tools are used in many static organizations, but this is mostly to catch anomalies in service provision rather than to feed automatically information back to every-day decision-making.

Most crucially, all dynamic organizations concentrate on services characterized by increasing returns to scale, i.e., their service outputs have significantly increased due to ICT-related investments. With the ability to increasingly digitize their services while also enlarging their user base, they have been able to escape from the so-called cost-disease trap. Importantly, all dynamic services are being exported (i.e., they are increasingly used by foreign citizens and/or organizations), making it possible to increase organizational revenues, enlarge the user base and thus reinforce the development of technological capacities. 
Secondly, market feedback provides a rather mixed influence on public sector technological change. Overall, the market capabilities tend to be fragmented when it comes to providing new technologies for public sector. Off-the-shelf products for public sector are mostly available in areas of back-office and support services, providing somewhat more dynamic environment there (all studied organizations have significantly changed their internal back-office information-processing routines and structures). When it comes to the core tasks, the studied organizations except for the postal services mostly utilize private sector tailor-made technologies. The outsourced tailor-made solutions come with considerable transaction costs and are often difficult to implement on-time, making it sometimes difficult to create positive feedback loops for further developments (e.g. the significant cost overruns and delays in developing a new central database for the Social Insurance Board severely interrupted the service provision in 2017 and culminated with a political scandal). We did not detect any significant positive market spill-overs in terms of new niche markets or capability building.

Interestingly, the core technologies of all the dynamic services are themselves technically not very complicated, thus limiting the potential negative feedback emerging from market transactions (the initial version of the e-residency platform was developed within months, the Tax Board has invested so far only MEUR 20 over the past two decades into ICT, the postal service relies heavily on off-theshelf parcel automates). In case of postal services the supply of the parcel equipment and software solutions by the market has been rapidly increasing, making it possible for the state-owned enterprise to also rapidly forge ahead its internal technological capacities.

Thirdly, in terms of network feedback, we can detect some evidence that dynamic organizations have stronger and positive network feedback loops than static organizations. For example, many technological innovations in tax services have been developed and implemented together with external stakeholders (e.g. the government $\mathrm{ClO}$ played a central role in the $1000 \mathrm{~K}$ bills case, while the industry associations eventually started to support the idea as well). The e-residency project was first heavily debated among a group of IT and other entrepreneurs, while a number of ministries, public 
agencies and industrial associations have been not only supporting the project, but extensively cooperating during the implementation phase. In parallel, the policy network has been the primary reason why the evolution of technological capacities have been slow in the field of emergency medical service. There are strong policy stakeholders in this field (physicians, autonomous service providers, local governments) whose technological capabilities as well as interest diverge from the government, but who have considerable power over the policy process.

On the whole, static organizations that have experienced either slow change in their technological routines or have so far managed to experiment with limited number of their services are constantly struggling to deliver minimum level services on equal manner to each and every citizen, making control, legitimacy and stability - hierarchical feedback as a forth element-a key feedback source. As indicated above, the dynamic organizations, on contrary, were able at least partly ignore the universality (e-residency, postal services) or legitimacy (tax services) issues and use technological innovations in favor of their organizations. In fact, the Tax Board explicitly used new technological solutions to impose more control and authority over markets. Many interviewees admitted that austerity policies have brought technology to the fore as a potential solution to increase organizational productivity, yet this is in most cases not measured directly (see also under citizen's feedback section above). The rhetoric of productivity is, however, key in communicating the need and impact of technology both within organization (from management to street-level bureaucrats) and outside organization (citizens, networks, market, public sector in general (esp. budgetary negotiations)). Again, dynamic organizations differ here as their productivity change is very easy to understand (all investing heavily into ICT over the next years), whereas in static organizations this is more problematic as the causal link between technological capacity and organizational performance is more indirect ("how would you measure the cost of life in policing?").

The positive feedback loop is more likely to emerge in cases of organizations that have high level of autonomy, provide simple services and have no legacy systems dominating over their processes. For example, one can argue that the rapid technological change in Tax Board has taken place because of 
the relatively simple tax system in Estonia and small size of the country. Similarly, the postal service switched to entirely new and emerging service area, effectively avoiding the traps of the old service model based on universal postal system. E-residency as a service platform was developed from scratch. In other areas, the services are much more integrated with other service areas and the centralized data exchange infrastructure, limiting the autonomy to make radical changes and rising the coordination costs associated with new developments.

Interestingly, most of the interviewees admitted that public procurement regulation is not a significant barrier to technological change. This is surprising and contrary to what we expected. However, this should be understood in context. As one interviewee put it: "I clearly see that public sector is far away from technological frontier and I cannot explain why. And although public procurement as such has not held us back, I do see the need to develop more in-house technical skills for us to be able to move faster." For static organizations outsourcing technological solutions, and in some cases (emergency medical service, police, social insurance) centralization of the core public sector capabilities on a ministerial level or in a dedicated agency, have led to rather limited inhouse technology skills (1-2 people in many cases). Relatedly, as in-house technological capabilities are limited, also relational capacity to search, understand and exploit new technologies is limited. This situation is further complicated by low IT skills among service provision staff in many sectors (e.g. nurses in welfare and emergency medical service, or even road engineers). All dynamic organizations had built strong technological skills directly into their organizations.

Another surprising finding was that apart from e-residency no public sector organization admitted that there was a pressure for technological change from parent ministries. This implies that in spite of political rhetoric related to austerity or gaining global technological leadership, policy-thinking on the ministerial level is almost completely technology-free in Estonia. Although some interviewees see the centralized ICT competence centers as problematic, it is often the centralized IT agencies that initiate technological change rather than the actual units responsible for service policy or provision, making the evolution of technological capacities closely linked to how the centralized units interact 
with the actual public service providers and implement technology projects. Many respondents claimed that there is a generic lack of technological champions both in policy-making as well as service provision organizations. This means that technological change depends not necessarily on the logic of public service, but on the external capacities of specialized public IT agencies.

When it comes to evaluation practices then ICT-based solutions (better overview of state-of-affairs through data analytics and monitoring) have enabled many organizations to increase their capabilities to articulate their problems for public sector stakeholders and, inter alia, increase their budgets. As a result, increased data capabilities can reinforce further technological investments. At the same time, in case of static services the external effects are not usually systematically accounted for in the service evaluation exercises, providing no strong feedback for further technological investments and change.

\section{Concluding discussions}

One of the most striking paradoxes that emerged from the Estonian case study is related to the uneven and mostly slow rate of change in technological capacities in seemingly technology-friendly context. On the one hand, there is a strong austerity-driven push for budget cutbacks and productivity increases, and most of the interviewed public sector leaders were very knowledgeable about the potential of technology in their fields, and no interviewee identified any privacy related issues that would act as a major hindrance to technological developments. And yet, on the other hand, almost all interviewed senior civil servants acknowledged that their organizations are either very or relatively far from technological frontier (in the sense of both creating new or adapting existing technological solutions).

We use our framework of selection mechanisms to explain this puzzle and highlight why two diverging groups of organizations emerge: first group of (dynamic) organizations that show radical change in administrative capacity and become ambidextrous, and those (static organizations) who do not. Our analysis demonstrates that dynamic organizations were directly and positively influenced 
by the citizen feedback when user behavior was explicitly linked with technological innovations, policy networks when strong supportive coalition emerged, and hierarchical feedback when technology enabled to increase the control and legitimacy of the organizations concerned and when organizations possessed the authority to act autonomously and/or selectively. At the same time, the static organizations were mostly not able to integrate the user behavior directly into their feedback systems, experienced weak support or even resistance from policy networks, and anticipated limited gains in terms of increasing control, legitimacy and stability through technological innovations. Perhaps surprisingly the reinforcement effect emerging from market feedback to develop radically different technological routines can be considered as weak. This was so either because the technological solutions implemented were rather straightforward and assumed limited market transaction risks (dynamic organizations) or the market capabilities were too fragmented forming no strong supportive feedback patterns (static organizations). Here the context of Estonia is significant due to the relatively low complexity of public sector (1.3 million inhabitants and strong central government) and smallness of markets. As such, the dynamic organizations demonstrated high level of inter-organizational collaboration and network coordination capabilities, their recruitment focus was on acquiring people with new set of skills (data or technical), their strategic management revolved around business-case thinking and experimentation, and they were led by leaders possessing transformational leadership skills.

Overall, this article attempted to make three main contributions. First, we provided new insights into the underlining patterns of public sector technological evolution by focusing on organizations rather than on single technological solutions or projects. Second, based on the concept of technological capacity we proposed and tested a new approach to study technological change in public sector. Third, by focusing on Estonia, we demonstrated how the technological change affects the evolution of public organizations in an overall supportive digital environment. The Estonian cases show how technological advances (ease of use of new tech solutions, cheapness, layering of options) make both frameworks of administrative capacity (resources and authority) open-ended for internal (new 
division of tasks or even new prioritization of tasks) and external (new coordination pathways) changes of administrative capacity. Thus, along other contextual and internal factors that we know more about already, technology becomes an intrinsic factor in how administrative capacity evolves. Clearly, the feedback mechanisms may provide different results in different contexts, depending on the size of a country, public sector culture, the development level of markets and other factors. However, we believe that the presented framework proved to be a useful analytical approach for conducting such kind of analyses in other countries.

\section{Bibliography}

Barley SR (1990) The Alignment of Technology and Structure through Roles and Networks. Administrative Science Quarterly 35(1): 61-103.

Bass, Bernard M., and Ronald E. Riggio. (2006). Transformational Leadership. 2nd ed. Mahwan, NJ: Lawrence Erlbaum.

Baumol WJ (1967) Macroeconomics of unbalanced growth: the anatomy of urban crisis. The American economic review 57(3): 415-426.

Bloom N, Garicano L, Sadun R, and Van Reenen J (2009) The distinct effects of information technology and communication technology on firm organization. CEP Discussion Paper no. 927. London: Centre for Economic Performance.

Bozeman B (2002) Public-value failure: When efficient markets may not do. Public Administration Review, 62(2), 145-161.

Brown A, Fishenden J and Thompson M (2014) Digitizing Government. Understanding and Implementing New Digital Business Models. Houndsmill, Basingstoke: Palgrave Macmillan.

Cordella A and Willcocks, L., 2010. Outsourcing, bureaucracy and public value: Reappraising the notion of the "contract state". Government Information Quarterly, 27(1): 82-88. 
Coriat B and Weinstein O (2002). Organizations, firms and institutions in the generation of innovation. Research Policy 31(2): 273-290.

Crossan MM, Lane HW and White RE (1999). An organizational learning framework: From intuition to institution. Academy of Management Review, 24(3): 522-537.

Dosi G and Nelson RR (1994) An introduction to evolutionary theories in economics. Journal of Evolutionary Economics, 4(3), 153-172.

Dunleavy P, Margetts H, Bastow S and Tinkler J (2006) Digital Era Governance: IT Corporations, the State, and E-Government. Oxford: Oxford University Press.

Fountain JE (2001) Building the Virtual State: Information Technology and Institutional Change. Washington, D.C.: Brookings Institution Press.

Gil-Garcia R and Martinez-Moyano IJ (2007) Understanding the evolution of e-government: The influence of systems of rules on public sector dynamics. Government Information Quarterly, 24(2), 266290.

Hood C and Dixon R (2015) A Government that Worked Better and Cost Less?: Evaluating Three Decades of Reform and Change in UK Central Government. Oxford: Oxford University Press.

Janssen M and Estevez E (2013) Lean government and platform-based governance-Doing more with less. Government Information Quarterly 30: S1-S8.

Kalvet T (2012) Innovation: a factor explaining e-government success in Estonia. Electronic Government: an International Journal, 9(2), 142-157.

Karo E and Kattel R (20162017) Innovation and the State: Towards an evolutionary theory of policy capacity. In Wu, X. Howlett, M. and Ramesh, M. (eds.) Policy Capacity: State and Societal Perspectives. Houndmill, Basingstoke: Palgrave (forthcoming).

Kattel R and Raudla R (2013) The Baltic Republics and the crisis of 2008-2011. Europe-Asia Studies 65(3): 426-449. 
Kitchin R (2016) Reframing, reimagining and remaking smart cities. The Programmable City Working Paper 20. Available at: http://progcity.maynoothuniversity.ie/ (28.04.2017).

Lember, V; Kattel, R; Kalvet, T (2015) Quo vadis public procurement of innovation? Innovation: The European Journal of Social Science Research, 28 (3), 403-421.

Leonardi PM and Barley SR (2010) What's under construction here? Social action, materiality, and power in constructivist studies of technology and organizing. The Academy of Management Annals 4(1): 1-51.

March JG (1991) Exploration and Exploitation in Organizational Learning. Organization Science 2(1): 71-87.

Margetts H and Naumann A (2017) Government as a Platform: What can Estonia Show the World? Research Report. Available at: https://www.politics.ox.ac.uk/publications/government-as-aplatform-what-can-estonia-show-the-world.html (28.04.2017).

Nelson R and Winter S (1982). An Evolutionary Theory of Economic Change. Cambridge: The Belknap Press of Harvard University Press.

Margetts H and Dunleavy P (2013). The second wave of digital-era governance: a quasi-paradigm for government on the Web. Philosophical Transactions of the Royal Society A: Mathematical, Physical and Engineering Sciences 371: 20120382.

O'Reilly CA III and Tushman ML (2008) Ambidexterity as a dynamic capability: Resolving the innovator's dilemma. Research in Organizational Behavior 28: 185-206.

Orlikowski WJ (1992) The duality of technology: Rethinking the concept of technology in organizations. Organization Science 3(3): 398-427.

Osborne SP and Brown K (2013) Handbook of Innovation in Public Services. Cheltenham: Edward Elgar. 
Painter M and Pierre J (2005) Unpacking Policy Capacity: Issues and Themes. In Painter M and Pierre J

(Eds) Challenges to State Policy Capacity: Global Trends and Comparative Perspectives. Basingstoke: Palgrave Macmillan, 1-18.

Perez C (2002) Technological revolutions and financial capital: The dynamics of bubbles and golden ages. Cheltenham, Northampton: Edward Elgar.

Pollitt C (2012) Place and Technology. Oxford: Oxford University Press.

Pollitt C and Bouckaert G (2011) Public management reform: A comparative analysis-new public management, governance, and the Neo-Weberian state. Oxford: Oxford University Press.

Taylor, M Z (2016) The politics of innovation: why some countries are better than others at science and technology. Oxford: Oxford University Press.

Teece DJ (2009) Dynamic capabilities and strategic management: organizing for innovation and growth. Oxford: Oxford University Press.

Townsend AM (2013) Smart cities: Big data, civic hackers, and the quest for a new utopia. WW Norton \& Company.

Trist E (1981) The evolution of socio-technical systems. A conceptual framework and an action research program. Ontario Ministry of Labour.

Tõnurist P, Kattel R and Lember V (2017) Discovering Innovation Labs in the Public Sector: What They Are and What They Do? Public Management Review, 19(10): 1455-1479.

Zollo M and Winter SG (2002) Deliberate learning and the evolution of dynamic capabilities. Organization Science 13(3): 339-351. 